\title{
PEMBERDAYAAN SISWA SEKOLAH DASAR TENTANG PEMAHAMAN KONSEP SIFAT- SIFAT CAHAYA MELALUI MODEL INKUIRI TERBIMBING
}

\author{
Desi Susilawati \\ Pendidikan Dasar Pascasarjana Universitas Negeri Surabaya
}

\begin{abstract}
Abstrak
Penelitian ini bertujuan mendeskripsikan penerapan model inkuiri terbimbing pada materi sifat-sifat cahaya dalam memberdayakan siswa tentang pemahaman konsep IPA. Penelitian menggunakan metode eksperimen dengan rancangan penelitian yang digunakan adalah counterbalanced design. Subjek penelitian ini adalah siswa kelas V SDN Cilingga Kota Tasikmalaya. Model pembelajaran terdiri atas dua level, yaitu pembelajaran inkuiri terbimbing dan pembelajaran konvensional. Hasil penelitian menunjukkan bahwa keterlaksanaan pembelajaran inkuiri menunjukkan keterlaksanaan yang baik, aktivitas siswa dalam pembelajaran inkuiri terbimbing lebih tinggi adalah merancang eksperimen dan melaksanakan eksperimen, ada perbedaan rata-rata pemahaman konsep melalui inkuiri terbimbing dengan rata-rata pemahaman konsep dengan pembelajaran konvensional sehingga pemahaman konsep IPA pada inkuiri terbimbing lebih tinggi daripada pembelajaran konvensional.
\end{abstract}

Kata Kunci: pemahaman konsep, sifat-sifat cahaya, dan model inkuiri terbimbing

\begin{abstract}
This study aims to describe the application of guided inquiry model of the matter characteristics of light in empowering students understanding of science concepts. Research using experimental methods to design research is counterbalanced design. The subjects were students of class V SDN Cilingga Tasikmalaya. Learning model consists of two levels, namely the guided inquiry learning and conventional learning. The results showed that the inquiry learning keterlaksanaan showed good adherence to, the activity of students in higher learning guided inquiry is designing experiments and carry out experiments, there was an average difference of understanding concepts through guided inquiry with an average understanding of the concept of the conventional learning so understanding the concept of IPA on guided inquiry is higher than conventional learning.
\end{abstract}

Keywords: understanding the concept, characteristics of light, and the model of guided inquiry.

\section{PENDAHULUAN}

Perubahan dan perkembangan dalam setiap aspek kehidupan terjadi dengan cepat. Perkembangan yang terjadi dalam segala aspek kehidupan termasuk dalam bidang pendidikan akan terus berlanjut seiring dengan perkembangan bidang ilmu dan teknologi. Secara umum kita dapat memahami bahwa tantangan yang dihadapi oleh bangsa Indonesia pada abad ini adalah bersifat multidimensi. Oleh karena itu, perlu dipikirkan pendidikan yang mampu menjadi bekal hidup dalam menghadapi tantangan abad ini dan masa depan.

Kaitannya dengan hal tersebut, UNESCO melalui International Commision on Education for The $21^{\text {st }}$ Century memiliki tujuan mengubah dunia dengan mengusulkan empat pilar pendidikan, yaitu 1) belajar untuk mengetahui (learning to know), 2) belajar untuk melakukan (learning to do), 3) belajar untuk menjadi (learning to be), dan 4) belajar untuk bekerjasama (learning to live together) (dalam Jufri, 2013:175). Implemetasinya berarti bahwa proses pendidikan memungkinkan siswa menguasai cara memperoleh pengetahuan, berkesempatan menerapkan pengetahuan yang dipelajarinya, dan berinteraksi dengan sesama siswa sehingga mereka dapat mengembangkan potensi yang ada dan menemukan jati dirinya.

Dalam Undang-Undang Nomor 20 Tahun 2003 tentang Sistem Pendidikan Nasional, Pasal 1 ayat 1 disebutkan bahwa Pendidikan adalah usaha sadar dan terencana untuk mewujudkan suasana belajar dan proses pembelajaran agar peserta didik secara aktif mengembangkan potensi dirinya untuk memiliki kekuatan spiritual keagamaan, pengendalian diri, kepribadian, kecerdasan, akhlak mulia, serta keterampilan yang diperlukan dirinya, masyarakat, bangsa dan Negara. Berdasarkan pernyataan tersebut pendidikan merupakan proses pembelajaran yang diarahkan kepada perkembangan siswa untuk memiliki kekuatan spiritual keagamaan, pengendalian diri, kepribadian, kecerdasan, akhlak mulia, serta keterampilan yang diperlukan dirinya, masyarakat, bangsa, dan Negara.

Untuk dapat membangun masyarakat yang terdidik dan mampu menyesuaikan diri dengan tuntutan perkembangan ilmu dan teknologi abad ini, 
maka yang perlu dilakukan adalah menata sistem pembelajaran. Guru harus bisa menerapkan model pembelajaran yang baik sehingga siswa dapat mengamati, mempelajari dan memahami konsep ketika mempelajari suatu pengetahuan.

Sehubungan dengan hal itu, maka pembelajaran saat ini harus diarahkan pada pengembangan kompetensi siswa dalam melakukan tugas-tugas akademik berdasarkan standar kompetensi tertentu. Standar kompetensi umumnya meliputi pengetahuan, keterampilan, dan nilai-nilai dasar yang perlu dimiliki serta dapat direfleksikan dalam kebiasaan hidup sehari-hari.

Untuk mewujudkan pembelajaran yang dapat mengembangkan kompetensi di atas, model pembelajaran yang dianggap cocok yaitu model pembelajaran inkuiri. Hal ini disebabkan Abidin (2014:149) mengatakan bahwa model pembelajaran inkuiri merupakan suatu model pembelajaran yang dikembangkan agar siswa menemukan dan menggunakan berbagai sumber informasi dan ideide untuk meningkatkan pemahaman mereka tentang masalah, topik, atau isu tertentu.

Berdasarkan pernyataan di atas berarti penggunaan model pembelajaran inkuiri tidak hanya sebatas menjawab pernyataan atau mendapatkan jawaban yang benar, tetapi menuntut siswa untuk melakukan serangkaian proses eksplorasi, pencarian, eksperimen, penelusuran, dan penelitian. Sehingga, penerapan model ini membantu siswa memperoleh pengetahuan disertai pula dengan keterampilan yang lain.

Sementara itu, Suchman (Joyce, et.al:2009) mengemukakan bahwa tujuan model inkuiri ialah mengembangkan keterampilan kognitif dalam melacak dan mengolah data-data. Model ini ditujukan untuk meningkatkan kemampuan siswa dalam memahami konsep-konsep logis serta hubungan kausalitas dalam mengolah sendiri informasi secara produktif.

Coffman (2009) seperti dikutip oleh Abidin (2014:151) memandang model pembelajaran inkuiri sebagai sebuah model pembelajaran yang secara langsung melibatkan siswa untuk berpikir, mengajukan pertanyaan, melakukan kegiatan eksplorasi dan eksperimen sehingga siswa mampu menyajikan solusi atau ide yang bersifat logis dan ilmiah.

Berdasarkan pendapat di atas, model pembelajaran inkuiri dipandang berfungsi untuk membiasakan siswa mempelajari dan memecahkan masalah, berpikir kritis dan berasumsi, serta bertanggungjawab dalam mencapai pemahaman secara mandiri. Hal ini berarti model pembelajaran inkuiri benar-benar menantang siswa untuk aktif selama proses pembelajaran, mendorong untuk mengoptimalkan keterampilan proses dan mencapai pemahaman konsep atas apa yang sedang dipelajari.

Salah satu mata pelajaran yang dipelajari di sekolah guna melatihkan keterampilan proses atau metode ilmiah adalah mata pelajaran Ilmu Pengetahuan Alam (IPA). Pembelajaran IPA tidak hanya memberikan bekal pengetahuan saja tetapi keterampilan, sikap, dan nilai. Selain itu, seorang guru juga harus mampu mendorong siswanya untuk aktif di dalam pembelajaran dan memberikan pengalaman langsung sehingga pembelajaran menjadi bermakna.

Pembelajaran IPA menekankan pada pemberian pengalaman belajar siswa secara langsung difasilitasi untuk mengembangkan sejumlah keterampilan proses (kerja ilmiah), sikap ilmiah, dan berperilaku dalam memeroleh pengetahuan ilmiah tentang dirinya dan alam sekitar.

Menurut Khotimah (2013:20) tujuan IPA secara umum adalah agar siswa memahami konsep IPA dan keterkaitannya dengan kehidupan seharihari, memiliki keterampilan proses untuk mengembangkan gagasan tentang alam sekitar, mampu menerapkan berbagai konsep IPA untuk menjelaskan gejala alam, dan mampu menggunakan teknologi sederhana untuk memecahkan masalah yang ditemukan dalam kehidupan sehari-hari.

Guru hendaknya mendorong siswanya melihat masalah, merumuskannya dan berupaya untuk memecahkan masalah sesuai dengan kemampuannya sehingga siswa mengkontruksi pemahamannya sendiri. Pemberdayaan tentang pemahaman konsep pada siswa harus dimulai sejak awal. Jika pemahaman siswa tidak diberdayakan secara terus menerus dalam pembelajaran dimungkinkan kemampuan siswa dalam menyelesaikan berbagai permasalahan akan sangat kurang.

Kenyataan menunjukkan bahwa masih banyak guru yang memaknai pembelajaran sebagai kegiatan menyampaikan informasi dan pengetahuan kepada siswa. Guru belum melatihkan keterampilan proses dalam pembelajaran sehingga pemahaman konsep siswa terhadap suatu pengetahuan juga masih sangat kurang. Hal ini disebabkan kurangnya pengetahuan guru tentang model-model pembelajaran yang dapat melatihkan keterampilan tersebut, guru belum meluangkan waktu khusus untuk mengajarkan cara merencanakan percobaan langkah demi langkah serta perangkat pembelajaran 
yang kurang memadai untuk melatihkan keterampilan tersebut.

Konsep cahaya adalah nama yang diberikan manusia pada radiasi yang dapat dilihat oleh mata manusia. Cahaya merupakan gelombang elektromagnetik, yaitu gelombang yang getarannya adalah medan listrik dan medan magnet. Cahaya memiliki sifat-sifat yaitu, cahaya dapat merambat lurus, cahaya dapat menembus benda bening, cahaya dapat dipantulkan, cahaya dapat dibiaskan, dan cahaya dapat diuraikan. (Wulandari, 2013)

Konsep cahaya tersebut harus benar-benar dipahami oleh siswa. Anderson \& Krathwohl (2010: 105) menyatakan bahwa siswa dikatakan memahami apabila mereka dapat membangun makna dari pesan-pesan pembelajaran yang bersifat lisan, tulisan maupun gambar yang disampaikan melalui pengajaran, buku atau layar komputer. Proses-proses kognitif dalam kategori memahami meliputi menafsirkan, mencontohkan, mengklasifikasikan, merangkum, menyimpulkan, membandingkan dan menjelaskan. Menurut Purwanto (2006:44) pemahaman adalah tingkat kemampuan yang mengharapkan siswa mampu memahami arti atau konsep, situasi serta fakta yang diketahuinya.

Pemahaman konsep dapat dilatihkan dengan pembelajaran inkuiri terbimbing. Hal ini sejalan dengan teori belajar konstruktivisme. Nur (2008) menyatakan teori konstruktivisme menjelaskan bahwa siswa harus menemukan sendiri dan mentransformasikan sendiri suatu informasi kompleks apabila mereka menginginkan informasi itu miliknya sendiri.

Coffman (2009) mendefinisikan inkuiri sebagai pembelajaran yang berfokus pada upaya guru dalam mengajukan pertanyaan secara konsisten untuk meningkatkan pemahaman siswa terhadap materi pembelajaran selama proses belajar mengajar di dalam kelas.

Terdapat beberapa jenis inkuiri yang dapat digunakan sesuai dengan keadaan siswa yang bersangkutan, diantaranya adalah discovery learning, interactive demonstration, guided inquiry (inquiry lesson), inquiris labs, hypotical inquiry (Wening, 2010).

Berdasarkan hal tersebut, maka penting melakukan penelitian dengan menerapkan model inkuiri terbimbing untuk mengetahui pengaruhnya terhadap pemahaman konsep yang dipelajari siswa. Berdasarkan latar belakang, rumusan masalah dalam penelitian ini adalah "Bagaimana hasil penerapan model inkuiri terbimbing pada materi sifat-sifat cahaya dalam memberdayakan pemahaman konsep IPA siswa sekolah dasar?"

\section{METODE}

Penelitian ini termasuk penelitian eksperimen yang menguji efek/pengaruh penerapan inkuiri terbimbing dalam memberdayakan pemahaman konsep siswa. Penelitian dilaksanakan di kelas V SD Negeri Cilingga Kecamatan Mangkubumi Kota Tasikmalaya Provinsi Jawa Barat. Subjek penelitian siswa kelas V A sebanyak 35 orang dan V B sebanyak 35 orang.

Pelaksanaan penelitian mengikuti rancangan penelitian dengan menggunakan counterbalanced design. Rancangan ini dilakukan dalam beberapa tahap. Pada tahap ganjil, kelompok pertama dipakai sebagai kelompok eksperimen, dan kelompok ke dua sebagai kelompok kontrol (pembanding). Dan sebaliknya pada tahap genap, kelompok pertama dijadikan sebagai kelompok kontrol (pembanding) dan kelompok ke dua sebagai kelompok eksperimen. Berikut tabel rancangan penelitian counterbalanced design.

Tabel 1. Rancangan Penelitian Counterbalanced Design

\begin{tabular}{ccccccc}
$\begin{array}{c}\text { Kelom } \\
\text { pok }\end{array}$ & $\begin{array}{c}\text { Perlak } \\
\text { uan }\end{array}$ & $\begin{array}{c}\text { T } \\
\text { es }\end{array}$ & $\begin{array}{c}\text { Perlak } \\
\text { uan }\end{array}$ & $\begin{array}{c}\text { T } \\
\text { es }\end{array}$ & $\begin{array}{c}\text { Perlak } \\
\text { uan }\end{array}$ & $\begin{array}{c}\text { T } \\
\text { es }\end{array}$ \\
\hline A & X & O & - & O & X & O \\
B & - & O & X & O & - & O
\end{tabular}

(Sukmadinata, 2012)

Keterangan:

$\mathrm{X}$ : Perlakuan kelompok eksperimen dengan menerapkan model inkuiri terbimbing

- : Perlakuan kelompok kontrol dengan menerapkan pembelajaran

konvensional

$\mathrm{O}$ : Tes keterampilan proses dan pemahaman konsep

Pengumpulan data dilakukan dengan melakukan teknik validasi, observasi dan pemberian tes. Instrumen yang digunakan berupa lembar validasi kelayakan perangkat, lembar pengamatan keterlaksanaan pembelajaran, lembar aktivitas siswa, dan lembar tes. Teknik analisis data yang digunakan adalah deskriptif kualitatif. Untuk analisis data statistik menggunakan bantuan program SPSS Statistic 21.

\section{HASIL DAN PEMBAHASAN}

Hasil pengamatan terhadap keterlaksanaan pembelajaran inkuiri terbimbing pada penelitian 
dapat diamati dengan menggunakan lembar pengamatan keterlaksanaan pembelajaran model inkuiri terbimbing. Jumlah pengamat sebanyak dua orang. Aspek yang diamati meliputi pendahuluan, kegiatan inti, penutup, dan suasana kelas.

Berdasarkan data tentang keterlaksanaan tahapan-tahapan pembelajaran inkuiri terbimbing dapat dideskripsikan bahwa guru telah melaksanakan setiap tahapan pembelajaran sesuai dengan langkah-langkah yang disusun didalam RPP yang dirancang sesuai dengan tujuan penelitian. Hal ini terlihat dari nilai rata-rata skor dua pengamat untuk RPP 1 sebesar 3,64; rata-rata skor dua pengamat untuk RPP 2 sebesar 3,68; dan rata-rata skor dua pengamat untuk RPP 3 sebesar 3,86. Skor rata-rata keterlaksanaan pembelajaran pada tahap pendahuluan sebesar 3,83 dalam kategori baik, tahap kegiatan inti sebesar 3,67 dalam kategori baik, tahap penutup sebesar 3,50 dalam kategori baik, dan suasana kelas sebesar 3,89 dalam kategori baik.

Keterlaksanaan RPP tidak lepas dari peranan seorang guru dalam mengelola pembelajaran. Sanjaya (2009:197) mengatakan bahwa pembelajaran inkuiri akan efektif apabila: 1) guru mengharapkan siswa dapat menemukan sendiri jawaban dari suatu permasalahan, 2) jika bahan pelajaran yang diajarkan merupakan kesimpulan yang perlu pembuktian, 3) jika proses pembelajaran berangkat dari rasa ingin tahu siswa terhadap sesuatu, 4) jika guru mengajar pada sekelompok siswa yang mau dan mampu berpikir, 5) jika jumlah siswa yang belajar tidak terlalu banyak sehingga bisa dikendalikan guru, dan 6) jika guru memiliki cukup waktu untuk menggunakan model ini. Dengan demikian, persentase keterlaksanaan RPP yang baik ini menunjukkan bahwa guru dapat melaksanakan kegiatan pembelajaran sesuai dengan sintak-sintak pembelajaran inkuiri terbimbing.

Aktivitas siswa yang diamati selama pembelajaran adalah 1) merumuskan masalah, merumuskan hipotesis, merancang percobaan, melakukan eksperimen, mempresentasikan hasil percobaan, menjawab dan menanggapi pertanyaan kelompok, menyimpulkan hasil diskusi, 2) mendengarkan penjelasan guru, 3) bertanya kepada guru, 4) menyampaikan pendapat dan 5) aktivitas yang tidak relevan.

Aktivitas siswa pada pertemuan 1 yang paling dominan dalam pembelajaran adalah melaksanakan eksperimen yaitu sebesar $20,42 \%$. Kemudian kegiatan merancang eksperimen sebesar $18,32 \%$, dan aktivitas paling rendah adalah aktivitas yang tidak relevan sebesar $4,19 \%$. Rata-rata reliabilitas aktivitas siswa pada pertemuan pertama adalah $90,66 \%$.

Pada pertemuan 2, aktivitas siswa yang paling dominan dalam pembelajaran adalah melakukan eksperimen yaitu sebesar 25,84\%, kemudian merancang eksperimen sebesar $12,92 \%$, dan aktivitas paling rendah adalah aktivitas yang tidak relevan dengan sebesar $0,56 \%$. Rata-rata reliabilitas aktivitas siswa pada pertemuan kedua adalah $84,40 \%$.

Pada pertemuan 3, aktivitas siswa yang paling dominan dalam pembelajaran adalah melakukan eksperimen yaitu sebesar 25,50\%, kemudian merancang eksperimen sebesar 14,50\%, dan aktivitas paling rendah adalah aktivitas yang tidak relevan dengan sebesar $0 \%$. Rata-rata reliabilitas aktivitas siswa pada pertemuan ketiga adalah 93,52 \%. Hal ini menunjukkan bahwa guru bertindak sebagai fasilitator saja sedangkan siswa aktif melakukan kegiatan mandiri selama proses pembelajaran.

Arifin (1995:76) menjelaskan dalam pembelajaran dengan penemuan/inkuiri siswa didorong untuk dapat berpartisipasi secara aktif dalam pembelajaran untuk menemukan konsepkonsep atau prinsip-prinsip dengan melakukan eksperimen-eksperimen, dan guru juga mendorong siswa memiliki pengalaman dalam melakukan percobaan.

Pemahaman konsep siswa yang baik merupakan hasil belajar yang ingin dicapai melalui penerapan model inkuiri terbimbing. Rata-rata nilai tes pemahaman konsep pada tes ke-1 kelompok A pembelajaran dengan model inkuiri terbimbing sebesar 48 dan kelompok $\mathrm{B}$ pembelajaran konvensional sebesar 41. Pada tes ke-2 kelompok A pembelajaran konvensional rata-rata sebesar 60 dan kelompok B dengan pembelajaran inkuiri terbimbing rata-rata sebesar 72 . Pada tes ke-3 kelompok A dengan pembelajaran inkuiri terbimbing sebesar 83 sedangkan kelompok $\mathrm{B}$ dengan pembelajaran konvensional sebesar 63. Berdasarkan data di atas disimpulkan nilai rata-rata pemahaman konsep kelompok dengan pembelajaran inkuiri terbimbing lebih tinggi daripada nilai rata-rata pemahaman konsep kelompok dengan pembelajaran konvensional.

Pencapaian pemahaman konsep yang baik ini merupakan efek dari penerapan pembelajaran dengan menggunakan model inkuiri terbimbing. Hal ini berdasarkan Chiapetta \& Adams (dalam, Jufri 2013: 94) yang menyatakan bahwa pembelajaran inkuiri sangat berperan dalam proses perkembangan: 
1) pemahaman fundamental mengenai konsep, fakta, prinsip, hukum, dan teori, 2) keterampilan yang mendorong perolehan pengetahuan dan pemahaman mengenai fenomena alam, 3) pengayaan disposisi untuk menemukan jawaban pertanyaan dan menguji kebenaran pernyataan, 4) pembentukkan sikap positif terhadap sains, dan 5) perolehan pengertian mengenai sifat-sifat sains.

Tabel 2. Hasil Uji Normalitas Tes Pemahaman Konsep

\begin{tabular}{lllc}
\hline \multicolumn{1}{c}{ Tes ke } & Statistic & df & Sig. \\
\hline tes1_inkuiri & 0,146 & 35 & 0,057 \\
tes1_konvensional & 0,139 & 35 & 0,082 \\
tes2_inkuiri & 0,124 & 35 & 0,193 \\
tes2_konvensional & 0,135 & 35 & 0,104 \\
tes3_inkuiri & 0,133 & 35 & 0,121 \\
tes3_konvensional & 0,131 & 35 & 0,138 \\
\hline
\end{tabular}

Berdasarkan Tabel 2, nilai signifikansi untuk tes ke-1 pemahaman konsep dengan inkuiri terbimbing sebesar 0,057 sedangkan dengan pembelajaran konvensional sebesar 0,082. Nilai signifikansi untuk tes ke-2 pemahaman konsep dengan inkuiri terbimbing sebesar 0,193 sedangkan dengan pembelajaran konvensional sebesar 0,104 . Nilai signifikansi untuk tes ke-3 pemahaman konsep dengan inkuiri terbimbing sebesar 0,121 sedangkan dengan pembelajaran konvensional sebesar 0,138 . Karena signifikansi untuk seluruh variabel adalah lebih dari 0,05 , maka dapat disimpulkan bahwa populasi berdistribusi normal.

Menurut Priyatno (2010:9) signifikansi artinya meyakinkan atau berarti, dalam penelitian mengandung arti bahwa hipotesis yang telah terbukti pada sampel dapat diberlakukan pada populasi. Tingkat signifikansi $5 \%$ atau 0,05 artinya kita mengambil risiko salah dalam mengambil keputusan menolak hipotesis yang benar sebanyak-banyaknya $5 \%$ atau 0,05 .

Tabel 3. Hasil Uji Homogenitas Tes Pemahaman Konsep

\begin{tabular}{lll}
\hline Tes ke & Levene Statistic & Sig. \\
\hline 1 & 1,395 & 0,251 \\
2 & 0,512 & 0,816 \\
3 & 0,937 & 0,486 \\
\hline
\end{tabular}

Berdasarkan Tabel 3, hasil uji homogenitas tes ke-1 pemahaman konsep melalui pembelajaran inkuiri terbimbing terhadap pemahaman konsep melalui pembelajaran konvensional dengan signifikansi sebesar 0,251. Hasil uji homogenitas tes ke-2 dengan signifikansi sebesar 0,816, dan hasil uji homogenitas tes ke-3 dengan signifikansi sebesar 0,486. Karena nilai signifikansi lebih dari 0,05 maka dapat dikatakan bahwa varian dua kelompok adalah sama atau homogen.

Priyatno (2010:80) menyatakan bahwa jika angka Levene Statistic menunjukkan semakin kecil nilainya maka semakin besar homogenitasnya. Karena signifikansi pada hasil tes menunjukkan lebih dari 0,05, maka varian dinyatakan homogen.

Tabel 4. Hasil Uji t-Tes Pemahaman Konsep

\begin{tabular}{llllc}
\hline $\begin{array}{c}\text { Pembelajara } \\
\text { n }\end{array}$ & Mean & t & df & $\begin{array}{c}\text { Sig. } \\
(\mathbf{2}-\end{array}$ \\
& & & & $\begin{array}{c}\text { tailed } \\
\text { ) }\end{array}$ \\
\hline Konvension & 56,342 & - & 3 & 0,000 \\
al & 9 & 8,39 & 4 & \\
Inkuiri & 67,600 & 3 & & \\
Terbimbing & 0 & & & \\
\hline
\end{tabular}

Berdasarkan Tabel 2, nilai -t hitung < -t tabel yaitu $-8,393<-1,691$, dan signifikansi $0,000<0,05$ maka Ho ditolak, artinya bahwa ada perbedaan yang signifikan antara rata-rata nilai tes pemahaman konsep pada pembelajaran konvensional dengan rata-rata nilai tes pemahaman konsep pada pembelajaran inkuiri terbimbing. Nilai rata-rata (mean) pada pembelajaran konvensional adalah 56,3429 dan pada pembelajaran inkuiri terbimbing adalah 67,6000, berarti rata-rata nilai tes pemahaman konsep pada pembelajaran konvensional lebih rendah daripada nilai rata-rata pemahaman konsep pada pembelajaran inkuiri terbimbing.

\section{PENUTUP}

Berdasarkan analisis data dan diskusi pembahasan hasil penelitian, dikaitkan dengan rumusan masalah dan tujuan penelitian, dapat disimpulkan bahwa hasil penerapan model inkuiri terbimbing pada materi sifat-sifat cahaya adalah keterlaksanaan RPP menunjukkan keterlaksanaan yang baik, aktivitas siswa selama pembelajaran yang lebih dominan adalah merancang eksperimen dan melaksanakan eksperimen, pemahaman konsep siswa lebih tinggi daripada pemahaman konsep siswa dalam pembelajaran konvensional, hambatan yang dihadapi berkaitan dengan istilah baru bagi siswa, pengelolaan waktu dan ketidakberanian bertanya dan menyampaikan pendapat, dan ada perbedaan antara rata-rata pemahaman konsep melalui model inkuiri terbimbing dengan rata-rata 
pemahaman konsep melalui pembelajaran konvensional.

Berdasarkan simpulan, maka penulis dapat mengemukakan saran sebagai berikut: model inkuiri terbimbing perlu diterapkan pada topik yang sama di tempat lain, model inkuiri terbimbing perlu diterapkan juga dalam pembelajaran IPA pada materi/topik yang lain, penerapan inkuiri terbimbing memerlukan waktu yang lama sehingga diperlukan penambahan waktu yang cukup, dan rasa percaya diri siswa perlu ditingkatkan dengan memotivasi siswa supaya berani bertanya dan menyampaikan pendapatnya.

\section{DAFTAR PUSTAKA}

Abidin, Y. (2014). Desain Sistem Pembelajaran Dalam Konteks Kurikulum 2013. Bandung: PT Refika Aditama.

Anderson \& Krathwohl. (2010). Kerangka Landasan untuk Pembelajaran, Pengajaran, dan Asesmen, Revisi Taksonomi Pendidikan Bloom. Yogyakarta: Pustaka Pelajar.

Arifin, M. (1995). Pengembangan Program Pengajaran Bidang Studi Kimia. Surabaya: Airlangga University Press.

Coffman, T. (2009). Enganging Students Through Inquiry-Oriented Learning and Technology. New York: Rowman\&Littlefiled Education.

Ibrahim, M. (2005). Asesmen Berkelanjutan: Konsep dasar, tahapan pengembangan dan contoh. Surabaya: Unesa University Press

Joyce, B., Weil, M., and Calhoun, E. (2009). Models of Theaching (Eighth Edition). New Jersey, USA: Allyn \& Bacon.

Jufri, W. (2013). Belajar dan Pembelajaran Sains. Bandung: Pustaka Reka Cipta

Khotimah, K. (2013). Pengembangan Perangkat Pembelajaran Berdasarkan Model Inkuiri Terbimbing Dalam Rangka Melatihkan Keterampilan Proses Siswa (Tesis tidak dipublikasikan). Surabaya: Universitas Negeri Surabaya

Kuhlthau, C.C., Maniotes, L.K., Caspari, A.K. (2007). Guided Inquiry: Learning in the $21^{\text {st }}$ century. London: Libraries Unlimited

Nur, M. (2008). Pengajaran Berpusat Pada Siswa Dan Pendekatan Konstruktivis Dalam Pengajaran. Surabaya: Unesa University Press.

Priyatno, D. (2010). Paham Analisa Statistik Data dengan SPSS. Yogyakarta: MediaKom
Purwanto, M. N. (2006). Prinsip-prinsip dan teknik Evaluasi Pengajaran. Bandung: PT. Remaja Rosdakarya.

Sanjaya, W. (2009). Strategi Pembelajaran Berorientasi Standar Proses Pendidikan. Jakarta: Kencana Prenada Media Group.

Sukmadinata, N. S. (2012). Metode Penelitian Pendidikan. Bandung: PT Remaja Rosdakarya

Tim Dosen Fisika. (2013) Bahan Belajar Mandiri Cahaya dan Alat Optik. Tersedia.[Online].File.upi.edu/Direktori/DU AL_MODES/KONSEP_DASAR_FISIKA/B BM_8-(Cahaya_dan _alat_optik)_KD_Fisika.pdf. diakses 3 Januari 2015.

Tim Penyusun. (2014). Pedoman Penulisan Tesis dan Disertasi. Surabaya: Universitas Negeri Surabaya

Undang-Undang Nomor 20 Tahun 2003 tentang Sistem Pendidikan Nasional.

Wenning, C. J. (2010). Levels Of Inquiry:Using Inquiry Spectrum Learning Sequences To Teach Science. Journal Education and Learning. Vol. 5 No. 4, pp.1-9.

Wulandari. R. (2013). Materi IPA Kelas 5 SD: Sifat cahaya. [Online]. Tersedia: http://ipa5sd.blogspot.com/2013/06/sifatcahaya.html. Diakses 17 Desember 2014 